\title{
PERBANDINGAN FORCED VITAL CAPACITY PARU PADA ATLET RENANG MANADO DAN BUKAN ATLET RENANG DI SULAWESI UTARA
}

\author{
${ }^{1}$ Situmorang B. A \\ ${ }^{2}$ Lintong F \\ ${ }^{2}$ Supit W \\ ${ }^{1}$ Kandidat Skrispsi Fakultas Kedokteran Universitas Sam Ratulangi Manado \\ ${ }^{2}$ Bagian Fisika Kedokteran Universitas Sam Ratulangi Manado \\ Email: Situmorang_gita@yahoo.com
}

\begin{abstract}
Lung is a vital organ that has a function in the human body. Lung function as the human respiratory system. Respiratory literally means the movement of oxygen from the atmosphere and reach the $\mathrm{O} 2$ cell and release carbon dioxide $\mathrm{CO}_{2}$ is required in the normal functioning of cells in the body. Pool is one of the most powerful aerobic exercise because it involves all the muscles in order to prime the body and as a result provide better overall results compared with other sports. Respiratory capacity doubled during maximal exercise than at rest. The purpose of this research is to know the difference Forced Vital Capacity on the athletes and not athlete swimming pool in North Sulawesi. The study design was a cross sectional analytic survey (cross-sectional) or only done once in a given time. The research location is housed in the department of Prof.. Dr. R. D. Kandou Manado. The samples taken were 30 studies. The results showed that the value of $\mathrm{p}=0.005<\alpha=0.01$, and concluded that there are very significant differences between the athlete and not the athlete swimming pool. Keywords: athlete pool, forced vital capacity, not the athlete pool
\end{abstract}

\begin{abstract}
Abstrak: Paru merupakan organ yang mempunyai fungsi vital dalam tubuh manusia. Paru berfungsi sebagai alat pernafasan manusia. Pernafasan secara harafiah berarti pergerakan oksigen $\mathrm{O}_{2}$ dari atmosfer menuju ke sel dan keluarnya karbondioksida $\left(\mathrm{CO}_{2}\right)$ dari sel ke udara bebas. Pemakaian $\mathrm{O}_{2}$ dan pengeluaran $\mathrm{CO}_{2}$ di perlukan untuk menjalankan fungsi normal sel dalam tubuh. Renang merupakan salah satu olahraga aerobik yang paling berdaya guna karena melibatkan seluruh otot utama tubuh dan sebagai hasilnya memberikan hasil keseluruhan yang lebih dibanding dengan olahraga-olahraga lain. Kapasitas pernafasan meningkat dua kali lipat pada saat berolahraga maksimal dibanding saat istirahat. Tujuan dari penelitian ini yaitu mengetahui perbedaan Forced Vital Capacity ( FVC ) pada atlit renang dan bukan atlit renang di Sulawesi utara. Penelitian ini merupakan penelitian analitik. Desain penelitian yaitu cross sectional atau studi potong lintang, dimana pengukuran hanya dilakukan satu kali pada satu saat pada suatu populasi di wilayah tersebut. Hasil penelitian ini menunjukkan bahwa nilai $\mathrm{p}=$ $0.005<\alpha=0,01$, dan dapat disimpulkan bahwa terdapat perbedaan yang sangat bermakna antara atlit renang dan bukan atlit renang.
\end{abstract}

Kata Kunci: atlit perenang, bukan atlit perenang, kemampuan kapasitas vital paru.

Udara merupakan komponen lingkungan yang dibutuhkan bagi kelangsungan hidup manusia. Itulah sebabnya pengambilan udara oleh tubuh dilakukan secara terus menerus. Setiap hari jumlah udara yang keluar masuk saluran pernapasan sekitar 10 $\mathrm{m}^{3}$ per orang. Dalam menjalankan proses pengambilan udara, tubuh membutuhkan berbagai macam organ diantrannya adalah paru. $^{1}$ Paru merupakan organ yang 
mempunyai fungsi vital dalam tubuh manusia. Paru berfungsi sebagai alat pernafasan manusia, pernafasan secara harafiah berarti pergerakan oksigen $\mathrm{O}_{2}$ dari atmosfer menuju ke sel dan keluarnya karbondioksida $\left(\mathrm{CO}_{2}\right)$ dari sel ke udara bebas. Pemakaian $\mathrm{O}_{2}$ dan pengeluaran $\mathrm{CO}_{2}$ di perlukan untuk menjalankan fungsi normal sel dalam tubuh. $^{2}$

Pemakaian $\mathrm{O}_{2}$ dan pengeluaran $\mathrm{CO}_{2}$ sangat berperan penting dalam menjaga fungsi normal sel dalam tubuh manusia. Sehingga manusia dapat menjalankan kegiatan sehari-hari dengan baik. Dalam hal ini Paru sebagai organ vital yang mengatur pemakaian $\mathrm{O}_{2}$ dan pengeluaran $\mathrm{CO}_{2}$ memiliki memiliki kemampuan kapasitas yang baik guna menjaga ketahanan fisik dan kesegaran jasmani yang optimal. Untuk menjaga kemampuan capasitas vital paru yang baik maka di perlu dilakukan beberapa kegiatan diantaranya adalah olahraga. ${ }^{3}$

Berbagai aktivitas olahraga yang dilakukan manusia bertujuan untuk meningkatkan kualitas fisik sumber daya manusia, terutama apabila dilakukan secara benar dan teratur. Latihan olahraga merupakan suatu aktivitas aerobik, yang terutama bermanfaat untuk meningkatkan dan mempertahankan kesehatan dan daya tahan jantung, paru, peredaran darah, otot-otot, dan sendi-sendi. ${ }^{4}$ Olahraga untuk orang normal dapat meningkatkan kesegaran dan ketahanan fisik yang optimal. Pada saat berolahraga terjadi kerjasama berbagai otot tubuh yang di tandai dengan perubahan kekuatan otot, kelenturan otot, kecepatan reaksi, ketangkasan, koordinasi gerakan dan daya tahan (endurance) sistim kardio-respirasi. ${ }^{5}$

Renang adalah olahraga yang kompetitif dan kegiatan rekreasi yang terdiri dari berbagai gerakan yang mendorong tubuh melalui air. ${ }^{6}$ Renang juga merupakan salah satu olahraga aerobik yang paling berdaya guna karena melibatkan seluruh otot utama tubuh dan sebagai hasilnya memberikan hasil keseluruhan yang lebih dibanding dengan olahraga-olahraga lain. Kapasitas pernafasan meningkat dua kali lipat pada saat berolahraga maksimal dibanding saat istirahat. ${ }^{7}$ Respon tubuh terhadap olahraga merupakan hasil dari respon koordinasi sistem organ, termasuk jantung, paru, pembuluh darah perifer, otot yang olahraga dan sistem endokrine. ${ }^{8}$

Berdasarkan penelitian dari Muchsin, Kiyatno, Suradi pada bulan Januari 2011 untuk pengukuran Volume Tidal dan $\mathrm{VO}_{2}$ maksimal pada berbagai cabang olahraga, didapatkan hasil pengukuran untuk atlit renang yaitu, Volume Tidal bernilai 709,2 (ml) dan $\mathrm{VO}_{2}$ maksimal bernilai 73,91 (ml/kgbb/menit). ${ }^{9}$ Sedangkan untuk pengukuran Forced Vital Capacity (FVC) belum diketahui hasilnya. Berdasarkan latar belakang tersebut maka peneliti tertarik untuk melakukan penelitian tentang perbandingan Forced Vital Capacity (FVC) pada atlit renang dan bukan atlit renang di Sulawesi Utara.

\section{METODE}

Penelitian ini merupakan penelitian analitik. Desain penelitian yaitu cross sectional atau studi potong lintang, dimana pengukuran hanya dilakukan satu kali pada satu saat pada suatu populasi di wilayah tersebut. Dilakukan pada bulan Oktober 2012 sampai Desember 2012 di POLI Interna di Rumah Sakit Umum Pusat Prof. Dr. R. D. Kandou Manado. Sampel yang menjadi subjek penelitian yaitu atlit renang di Tomohon yang berusia 15-20 tahun, dan bukan atlit renang di Manado yang berusia 15-20 tahun yang berjumlah 30 responden.

\section{HASIL}

Penelitian ini dilakukan terhadap Atlit renang di Tomohon dan bukan Atlit renang di Manado yang berjumlah total 30 responden.

\section{Data Karakteristik}

Tabel 1. Distribusi responden menurut umur

\begin{tabular}{ccc}
\hline Umur & $\mathbf{N}$ & $\mathbf{\%}$ \\
\hline $15-16$ & 6 & 20.0 \\
$17-18$ & 5 & 16.7 \\
$19-20$ & 19 & 63.3 \\
\hline Total & 30 & 100.0 \\
\hline
\end{tabular}


Tabel 2. Distribusi responden menurut tinggi badan

\begin{tabular}{ccc}
\hline TB & $\mathbf{n}$ & $\mathbf{\%}$ \\
\hline$<160$ & 14 & 46.7 \\
$160-170$ & 12 & 40.0 \\
$>170$ & 4 & 13.3 \\
\hline Total & 30 & 100.0 \\
\hline
\end{tabular}

Tabel 3. Distribusi responden menurut berat badan

\begin{tabular}{ccc}
\hline $\mathbf{B B}$ & $\mathbf{N}$ & $\mathbf{\%}$ \\
\hline$<50$ & 10 & 33.3 \\
$50-60$ & 12 & 40.0 \\
$>60$ & 8 & 26.7 \\
\hline Total & 30 & 100.0 \\
\hline
\end{tabular}

Tabel 4. Nilai FVC (Liter) pada atrli renang

\begin{tabular}{ccc}
\hline FVC & $\mathbf{n}$ & $\mathbf{\%}$ \\
\hline 2.28 & 1 & 6.7 \\
2.79 & 1 & 6.7 \\
2.80 & 1 & 6.7 \\
2.93 & 1 & 6.7 \\
2.99 & 1 & 6.7 \\
3.04 & 1 & 6.7 \\
3.05 & 1 & 6.7 \\
3.14 & 1 & 6.7 \\
3.16 & 1 & 6.7 \\
3.88 & 1 & 6.7 \\
4.09 & 1 & 6.7 \\
4.25 & 1 & 6.7 \\
4.74 & 1 & 6.7 \\
4.85 & 1 & 6.7 \\
4.86 & 1 & 6.7 \\
\hline Total & 15 & 100.0 \\
\hline
\end{tabular}

Tabel 5. Hasil statistik nilai FVC pada atlit renang

\begin{tabular}{ccccc}
\hline FVC & mean & Std.deviasi & min & max \\
\hline $\begin{array}{c}\text { Atlit } \\
\text { renang }\end{array}$ & 3.5233 & 0.84445 & 2.28 & 4.86 \\
\hline
\end{tabular}

\section{BAHASAN}

Pada analisis univariat didapatkan responden yang memiliki usia terendah yaitu 17-18 tahun berjumlah 5 orang dengan persentase $16,7 \%$ dan responden yang memiliki usia tertinggi yaitu 19-20 tahun
Tabel 6. Nilai FVC (liter) pada bukan atlit renang

\begin{tabular}{ccc}
\hline FVC & $\mathbf{N}$ & $\mathbf{\%}$ \\
\hline 2.00 & 1 & 6.7 \\
2.16 & 1 & 6.7 \\
2.21 & 1 & 6.7 \\
2.35 & 1 & 6.7 \\
2.41 & 1 & 6.7 \\
2.58 & 1 & 6.7 \\
2.64 & 1 & 6.7 \\
2.72 & 1 & 6.7 \\
2.73 & 1 & 6.7 \\
2.85 & 2 & 13.3 \\
3.14 & 1 & 6.7 \\
3.22 & 1 & 6.7 \\
3.93 & 1 & 6.7 \\
4.56 & 1 & 6.7 \\
\hline Total & 15 & 100.0 \\
\hline
\end{tabular}

Tabel 7. Hasil statistik nilai FVC pada bukan atlit renang

\begin{tabular}{ccccc}
\hline FVC & mean & Std.deviasi & min & Max \\
\hline $\begin{array}{c}\text { Bukan } \\
\text { atlit }\end{array}$ & 2.8233 & 0.68143 & 2.00 & 4.56 \\
renang & & & & \\
\hline
\end{tabular}

berjumlah 19 orang dengan persentase $63,3 \%$. Pada penelitian yang dilakukan oleh Martiem Mawi di dapatkan bahwa semakin bertambahnya usia maka nilai rata-rata FVC semakin menurun. ${ }^{10}$

Pada pengukuran tinggi badan didapatkan responden yang memiliki tinggi badan $<160 \mathrm{~cm}$ berjumlah 14 orang dengan persentase $46,7 \%$. Pada pengukuran berat badan didapatkan responden dengan berat badan terbanyak adalah 50-60 kg berjumlah 12 orang dengan persentase $40 \%$, dan responden yg memiliki berat badan $<50 \mathrm{~kg}$ berjumlah 10 orang dengan persentase $33.3 \%$, sedangkan responden yang memiliki berat badan $>60 \mathrm{~kg}$ berjumlah 8 orang dengan persentase $26,7 \%$. Pada penelitian yang dilakukan oleh dr.Deasy Silviasari Madina didapatkan bahwa nilai kapasitas vital paru lebih dipengaruhi oleh karakteristik fisik seperti tinggi badan dan berat badan atlet dari pada olahraga yang dilakukan atlet tersebut. ${ }^{7}$

Pada Pengukuran nilai FVC (Forced 
Vital Capacity) pada kelompok atlit renang dengan menggunakan alat spirometri didapatkan responden yang mempunyai FVC terendah berjumlah satu orang dengan nilai FVC 2,28 liter, dan responden yang mempunyai FVC tertinggi berjumlah 1 orang dengan nilai 4.86 liter. Hasil statistik nilai FVC pada atlit renang didapatkan nilai mean 3.5233 dengan standar deviasi 0.84445 . Sedangkan pada pengukuran nilai FVC (Forced Vital capacity) pada kelompok bukan atlit renang ditemukan 2 responden yang memiliki nilai FVC 2.85 liter dan Satu orang dengan nilai FVC paling rendah yaitu 2.00 liter dan yang paling tinggi nilai FVC nya yaitu 3.93 liter. Hasil statistik nilai FVC pada kelompok bukan atlit renang didapatkan nilai mean 2.8233 dengan standar deviasi 0.68143. Berdasarkan hasil analisis dengan menggunakan uji MannWhitney U didapatkan perbedaan yang sangat bermakna pada FVC kelompok bukan atlit renang dan atlit renang dengan $\mathrm{p}=0.005<\alpha=0.01$.

\section{SIMPULAN}

Berdasarkan hasil penelitian yang dilakukan, maka dapat disimpulkan;

1. Distribusi berdasarkan golongan umur didapatkan umur terbanyak terdapat pada umur 19-20 tahun sebanyak 19 orang $(63,3 \%)$ dan yang paling sedikit adalah umur 17-18 tahun sebanyak 5 orang dengan persentase $16,7 \%$.

2. Distribusi menurut tinggi badan didapatkan hasil tinggi badan terbanyak terdapat pada tinggi badan $<160 \mathrm{~cm}$ sebanyak 14 orang $(46,7 \%)$ dan yang paling sedikit adalah tinggi badan $>170$ cm sebanyak 4 orang dengan persentase $13,3 \%$.

3. Distribusi menurut berat badan didapatkan hasil berat badan terbanyak terdapat pada berat badan 50-60 kg sebanyak 12 orang $(40,0 \%)$ dan yang paling sedikit adalah berat badan $>60 \mathrm{~kg}$ sebanyak 8 orang dengan persentase 26,7\%.

4. Berdasarkan hasil uji Mann-Whitney U, didapatkan bahwa terdapat perbedaan yang sangat bermakna pada nilai FVC kelompok bukan atlit renang dan kelompok atlit renang $\quad(p=0.005$ $<\alpha=0.01$ ).

\section{DAFTAR PUSTAKA}

1. Khumaidah. Analisis Faktor-faktor Yang berhubungan Dengan Gangguan Fungsi Paru Pada Pekerja Mebel PT Kota Jati Furnindo Desa Suwawal Kecamatan Mlonggo Kabupaten Jepara. Semarang. (Tesis). Universitas Diponegoro; 2009

2. Pardede Y. Penyakit Paru Pasien Rawat Inap di Bagian / SMF Ilmu Penyakit Dalam FK UNSRAT/ BLU RSUP Dr. R. D. Kandou Manado. (Skripsi). Manado. Universitas Sam Ratulangi; 2012.

3. Dewi C.M. Hubungan Antara Peningkatan Kekuatan Otot Dada Dengan Peningkatan Nilai Arus Puncak Ekspirasi. Semarang. Universitas Diponegoro; 2006.

4. Syatria A. Pengaruh Olahraga Terprogram Terhadap Tekanan Darah pada Mahasiswa Fakultas Kedokteran Universitas Diponegoro yang Mengikuti Ekstrakurikuler Basket. (Skripsi). Semarang. Universitas Diponegoro; 2006 .

5. Madina DS. Nilai Kapasitas Vital Paru dan Hubungannya dengan Karakteristik Fisik pada Atlet Berbagai Cabang Olahraga. (Tesis). Bandung. Universitas Padjadjaran. 2007.

6. Fakta Tentang Berenang dan Manfaat Kesehatan. Fisioterapi. 2013. Available online at http://www.fisioterapimakassar. info/fakta-tentang-berenang-dan-manfaatkesehatan.html(Accessed 20 Januari 2013).

7. Rosetya MI. Perbedaan antara Nilai Arus Puncak Ekspirasi Sebelum dan Sesudah Olahraga Renang Selama Dua Belas Minggu. (Skripsi). Semarang. Universitas Diponegoro. 2011.

8. Adiwinanti $\mathrm{W}$. Pengaruh Intervensi Olahraga di Sekolah Terhadap Indeks Masa Tubuh dan Tingkat Kesegaran Kardio respirasi pada Remaja Obesitas. (Tesis). Semarang. Universitas Diponegoro. 2008.

9. Doewes M, Kiyatno, Suradi. Kontribusi Sistem Respirasi Terhadap $\mathrm{VO}_{2}$ Maks. J Respir Indo. 2011: 31: 1.

10. Mawi M. Nilai Rujukan Spirometri Untuk Lanjut Usia Sehat. Universa Medicina. 2005;24:3. 